\title{
ON THE BIOLOGY OF THE EAST ASIAN SEED BEETLE, MEGABRUCHIDIUS DORSALIS (COLEOPTERA, CHRYSOMELIDAE, BRUCHINAE), AN ADVENTIVE SPECIES FOR UKRAINE
}

\author{
I. P. Lezhenina, Yu. V. Vasilieva \\ Kharkiv National Agrarian University named after V. V. Dokuchaev \\ p/o "Dokuchaevske-2", Kharkiv District, Kharkiv Region, 62483 Ukraine \\ E-mail: iryna57lezhenina@gmail.com \\ E-mail:vasilevaula952@gmail.com
}

I. P. Lezhenina (https://orcid.org/0000-0001-6510-4781)

Yu. V. Vasilieva (https://orcid.org/0000-0001-6989-6018)

On the Biology of the East Asian Seed Beetle, Megabruchidius dorsalis (Coleoptera, Chrysomelidae, Bruchinae), an Adventive Species for Ukraine. Lezhenina, I. P., Vasilieva, Yu. V. - Results of studying the biology of the East Asian seed beetle, Megabruchidius dorsalis (Fåhreus, 1839) (Chrysomelidae, Bruchinae), in the laboratory and field conditions of Kharkiv Region are presented. Mainly the fourth instar larvae and adult beetles hibernate in beans on the soil, in beans on trees and in shelters. Overwintered beetles appear in the first decade of May and do not need maturation feeding. The beans of honey locust (Gleditsia triacanthos L.) are an important factor in stimulating the start of oviposition. The beetles start oviposition only 8-11 days after emergence if only the seeds are proposed as a substrate, but if the beans are present, the beetles begin to mate and lay eggs in two days. Fertility of females in the laboratory is $110 \pm 40$ eggs. Egg mortality under natural conditions is 50-93\%. Megabruchidius dorsalis did not colonize the seeds of chickpeas (Cicer arietinum L.) and lentils (Lens culinaris Medik.). The beetle inhabited 10$40 \%$ of seeds of vigna (Vigna sesquipedalis Fruw) and common beans (Phaseolus vulgaris L.), but the 1st instar larvae died. Beetles feed on the seeds of Gleditsia of past years both in their natural habitat and in the Kharkiv Region for most of the growing season. Only in the second half of August they inhabit the seeds of the current year's crop. In the Kharkiv Region, M. dorsalis has three generations per year like in its native range in Sagamihara (Japan). The development duration of one generation in the laboratory is 37 days at $27^{\circ} \mathrm{C}$ and 41 days at $25^{\circ} \mathrm{C}$.

Key words: East Asian seed beetle Megabruchidius dorsalis, honey locust Gleditsia triacanthos, biology, phenology, feed plant. 


\section{Introduction}

Invasions of adventive insect species have become widespread since the beginning of the 2000s resulting in active penetration and expansion of quarantine species into Ukraine. The updated list of regulated pests of Ukraine has been replenished with new insect species. Some species from the list A-1 have already been identified in certain localities in Ukraine (About modification of the List of regulated harmful organisms, 2019). The study of the biology of alien species in the new territories is of fundamental and applied importance. The efforts of researchers are aimed at the identification of adventive species, compiling databases, as well as studying the possible consequences of their invasion.

In the 19th century, adventive species of bruchid beetles penetrated the territory of Europe, some of them became serious pests of leguminous crops and stocks, particularly Acanthoscelides obtectus Say, 1831 and Bruchus pisorum (Linnaeus, 1758). Some species have a quarantine status (Orlova-Bienkowskaja, 2019).

The Oriental genus Megabruchidius includes three species: M. dorsalis (Fåhreus, 1839), M. tonkineus (Pic, 1904), and M. sophorae Tuda \& Morimoto, 2004 (Tuda, Morimoto, 2004). Two related species, M. dorsalis and M. tonkineus, penetrated into Europe in the late 20th - early 21 st century. One species (M. dorsalis) was found in Ukraine in 2014 in Donetsk, in 2016 in Kyiv and in 2018 in Kharkiv Region (Martynov, Nikulina, 2014; Fursov, Nazarenko, 2015; Lezhenina, Vasylieva, 2018).

Information on East Asian seed beetle $M$. dorsalis biology in the native range significantly facilitates its study for new regions. In Japan, the seasonal population dynamics and some biology features of $M$. dorsalis were studied by Kurota \& Shimada (2002) in the northern (Tatsuna village, Nagano prefecture: $36^{\circ} 00^{\prime} \mathrm{N}$ $137^{\circ} 59^{\prime} \mathrm{E}$ ) and southern part of the range (Sagamihara city, Kanagawa prefecture: $35^{\circ} 34^{\prime} \mathrm{N} 139^{\circ} 23^{\prime} \mathrm{E}$ ). In the northern part of the beetle range, the temperature of the coldest month (January) is $-2^{\circ} \mathrm{C}$, of the warmest August $+23^{\circ} \mathrm{C}$; in the southern part, it is $+5.1^{\circ} \mathrm{C}$ and $+26.4^{\circ} \mathrm{C}$ respectively. Kurota \& Shimada (2002) have found that the lifecycle of East Asian seed beetle is closely related to the phenology of the host plant, Gleditsia japonica Miq., and in this regard revealed two unique features of these insects. The first one is that the beetles can develop in beans not only in a tree but also on the soil, which makes possible their multivoltine development. And the second feature: during the formation of a new bean crop, the females prefer to oviposit into the beans in the trees, even if the seeds are still small, underdeveloped, and of insufficient size for larvae development.

Such preference is due to the shortage (almost absence) of seeds on the soil during this period (second half of July). More than a month, from the second half of July to mid or end of August, this bruchid does not breed. In the southern part of Japan, larvae of different instars and adult beetles hibernate; in the north part larvae of the last age and adults hibernate (Kurota, Shimada, 2002).

In the natural range in Japan beetles emerge after wintering in late April - early May in the south and late May in the north and have two (North) or three (South) generations, while one generation develops 50 days at $24{ }^{\circ} \mathrm{C}$ and 70 days at $20{ }^{\circ} \mathrm{C}$ (Kurota, Shimada, 2001). The females prefer to oviposit into unripe green beans, the fecundity is $176.4 \pm 46.0$ eggs, each female oviposited only $21.9 \pm 8.0$ eggs into old dry beans (Kurota, Shimada, 2001).

Only males have maturation feeding by pollen and nectar on the flowering vegetation while females can be found on the host plants, regardless of the flowering phenology (Takakura, 2006). Studies on the sexual behavior of bruchids and the proportion between egg size and maturation feeding (Takakura, $2004 \mathrm{a}, \mathrm{b}$ ) show that the quality of males' maturation feeding generally did not affect the fertility of females and the size of eggs laid. In Europe, some aspects of the biology and morphology of the closely related species $M$. tonkineus have been studied in Hungary (György, 2007) however no data available on M. dorsalis biology in Europe.

Aim of the research is the study of biology and the ecology of $M$. dorsalis in the North-East of Ukraine (Kharkiv Region). Research tasks included studying a few biological features of $M$. dorsalis namely: hibernation; fecundity; duration of generation depending on temperature; a necessity in maturation feeding for adults; signaling factors for starting the oviposition; possibility to develop in other host plants and some morphometric parameters.

\section{Material and methods}

Biology of M. dorsalis was studied in the laboratory and under environmental conditions in 2018-2019. The study was carried out in the trees and fallen beans of Gleditsia triacanthos L. in the arboretum of the V. V. Dokuchaev Kharkiv National Agrarian University (KNAU) $\left(49^{\circ} 90^{\prime} \mathrm{N}, 36^{\circ} 45^{\prime} \mathrm{E}\right)$.

In order to recognize the necessity maturation feeding of adults, in May 2019, shrubbery and grassy flowering vegetation were trimmed once every five days (particularly Crataegus sp., Aesculus hippocastanum L., Spiraea sp., Sorbus sp., Viburnum, Taraxacum officinale F. H. Wigg., Brassicaceae, Ranunculaceae, Lamiaceae). Egg mortality in natural conditions was estimated by beans revision. Twenty beans were collected from the soil and 20 beans from harvested trees.

The beans of honey locust (Gleditsia triacanthos) colonized by M. dorsalis were collected and placed in an unheated room (fig. 1) for study in the laboratory. 


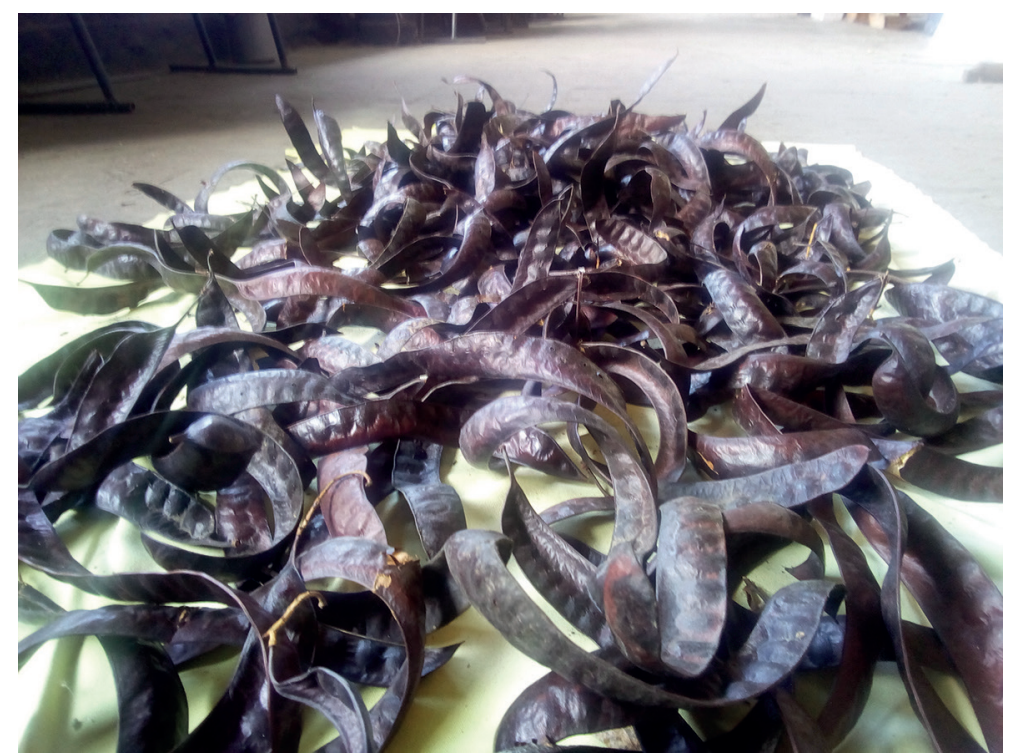

Fig. 1. Gleditsia triacanthos beans infested by the Megabruchidius dorsalis (Photo by I. P. Lezhenina).

Emerged beetles were used in further research on species biology. The beetles were kept indoors in Petri dishes and 0.5-liter glass jars. The relative humidity in the room was $75 \%$, the daily temperature during the development of the first laboratory generation was $27^{\circ} \mathrm{C}$, the second $25^{\circ} \mathrm{C}$, and the daily mean temperature was $26^{\circ} \mathrm{C}$ and $24^{\circ} \mathrm{C}$ respectively. Five males and five females were placed in each container with seeds of fodder plants, in total of 50 specimens. The source of water was wet cotton wool, which was changed once every three days and (or) daily spraying of the walls of the containers. Solutions of sugar and (or) honey in saturated cotton wool and raspberries were used for maturation feeding.

Also, everyday flowers with easily accessible nectar and pollen were provided for beetles: Rosa sp., Barbarea vulgaris R. Br., Berteroa incana L., Raphanus raphanistrum L., Philadelphus sp., Fragaria vesca $\mathrm{L}$. The temperature in the room was recorded daily using a household thermometer. Eggs and larvae were measured using a binocular stereoscopic microscope (MBS-9) ocular ruler (accurate to $0.1 \mathrm{~mm}$ ). Total of 50 specimens were measured.

To study the possibility of using alternative plants in larvae feeding, the seeds of one of such species were placed in Petri dishes or jars with beetles: vigna (Vigna sesquipedalis Fruw), lentils (Lens culinaris Medik.), kidney beans (Phaseolus vulgaris L.) and chickpea (Cicer arietinum L.).

Available internet resource (https://ru.climate-data.org/) was the source of weather data. Microsoft Excel software was used for data analysis, including descriptive statistics and plotting.

\section{Results}

Morphology. The morphology of adults of two closely related Asian Megabruchidius species was described in detail (Tuda, Morimoto, 2004; György, 2007). In this paper, we give some linear parameters of eggs and larvae of the first instar of $M$. dorsalis from Kharkiv population. The egg is elongated-oval, the posterior end is narrowed, covered with a white matte shell through which the yellow content is visible, the length of the egg is $0.84 \pm$ $0.01 \mathrm{~mm}$, the width is $0.30 \mathrm{~mm}$. The dark head of the larva becomes visible through the shell. Larva of the first age is light yellow, glassy-glossy with a brown head, short pectoral legs, slightly curved - the front and back ends are on the surface of the substrate, the body is raised between them, covered with rare thin rather long hairs, thicker at the rear back end. Body length $0.76 \pm 0.001 \mathrm{~mm}$, width $0.25 \pm 0.0001 \mathrm{~mm}$, head capsule $0.17 \pm 0.0006 \mathrm{~mm}$ wide.

Overwintering. According to our observations, beetles hibernate on winter beans of the current crop located on trees. The beetles (28\%), pupae (11\%), and larvae of the last (fourth) instar (61\%) hibernate on harvested legumes of previous years lying on the soil (Lezhenina, Vasilyeva, 2018). The first adults were recorded on May 7 on the flowers of hawthorn (fig. 2). 


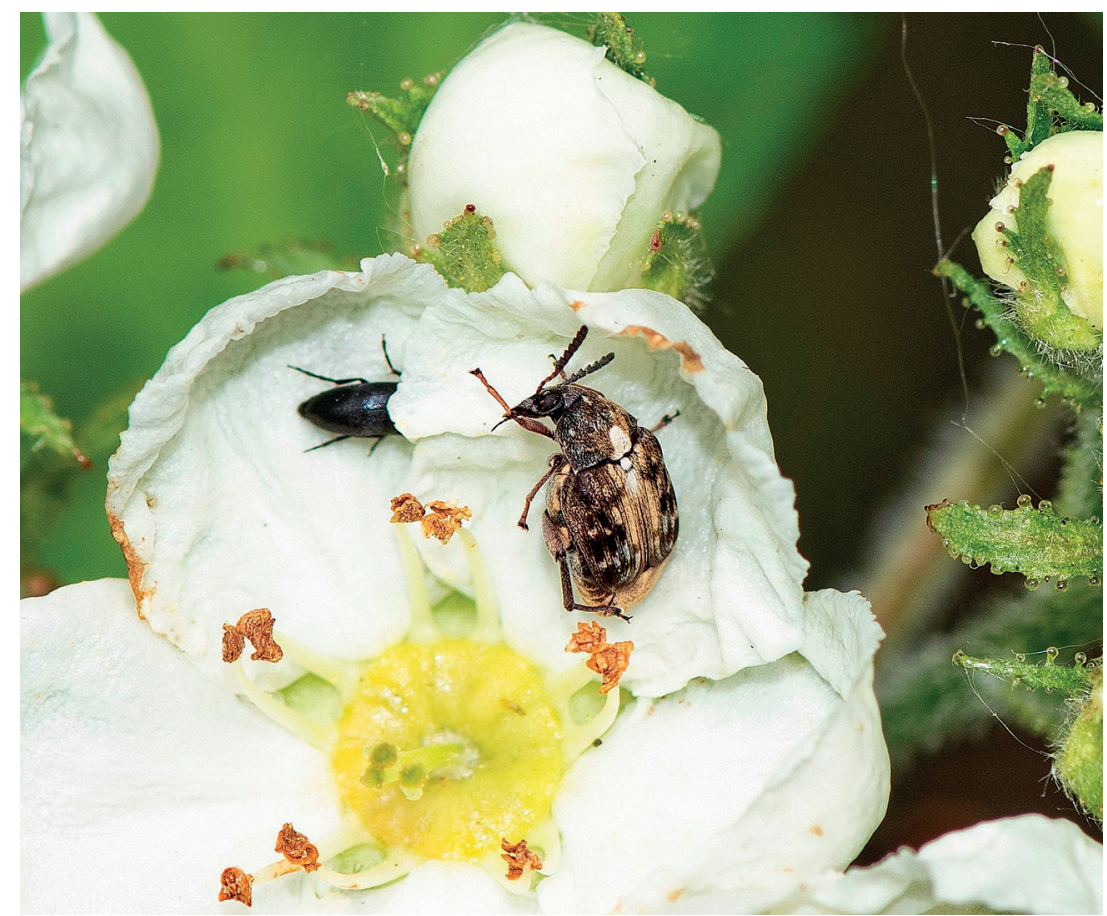

Fig. 2. Adults M. dorsalis on hawthorn flowers. May 7 (Photo by M. A. Filatov).

Maturation feeding. In order to clarify the need for additional nutrition for adult $M$. dorsalis, a series of experiments were carried out in the laboratory and under environmental conditions. In the laboratory, beetles infrequently sat on cotton wool with water and honey and sugar solutions for a short time. Flowers were not mostly attractive for adults as a feeding source. The most attractive things were water, applied with a brush on the walls of the containers and raspberries, however, the berries remained intact throughout the entire period. Finally, some of the laboratory insects were left indoors and continued to develop on 200 beans that were placed on the fabric. Additional food and water were not provided, but beetles actively laid eggs, from which viable progeny developed.

Thus, laboratory observations showed that adults use water occasionally; they do not need maturation feeding, and can survive without water. Also, we didn't catch a single specimen of $M$. dorsalis when using a hand net in flowering grassy and shrubby plants near the trees of honey locust. The only documentary source confirming the resumption of activity by the beetle is a photograph.

Oviposition. Under the environmental conditions of the Kharkiv Region, adult beetles (hibernated and developed from hibernated larvae and pupae) lay eggs on harvested beans from the past years, lying on the soil. Females lay eggs on the top and bottom parts of the beans randomly over their entire surface. For various reasons, egg mortality under environmental conditions is substantial (50-93\%), so that 7-50 \% of laid eggs can complete embryonic development. Larvae hatching from eggs laid on beans always browse an entrance hole at the location of the seed. In the laboratory, females laid eggs mainly on the walls of containers (jars), as well as on filter paper, flowers, and seeds of fodder plants. If the jars contained honey locust beans, the females first laid eggs on them, and later on the walls of the jars.

A signal for mating and laying eggs is the presence of a fodder substrate for larvae honey locust beans. It is known (Shoven, 1953) that insects live in a world of smells and communicate with the outside world through chemical communication. Honey locust beans emit strongly smelling substances - in our laboratory, 10 beans in a day created a 
high odor concentration unpleasant for humans. In this regard, for beetles' breeding, it is important that their hatching occurs in the presence of honey locust beans. Beetles that emerge from beans collected in the fall begin to mate almost immediately and lay eggs on the seeds offered to them. In the case when the insects were grown from seeds extracted from beans and were placed on the honey locust seeds, their mating and egg-laying were delayed. Such specimens mated and laid eggs on seeds 8-11 days after hatching.

To clarify the signaling role of beans in egg-laying, the beetles after hatching were placed on honey locust seeds on July 5, mating, and egg-laying has not been observed during the next three days. Some of the beetles (five males and five females) were placed on July 8 into a container with a honey locust branch, and on July 9, another portion of beetles (five males and five females) were placed into a container with honey locust beans. In two days, active oviposition began in the container with beans, while the beetles did not start laying eggs yet after six days in the containers with a branch and seeds.

Feed plants. Feed plants for M. dorsalis are seeds of species of the genera Gleditsia and the Gymnocladus of the family Fabaceae (György, 2007). A few trees (11) of honey locust grow nearby of the University (KhNAU), where we studied the biology of $M$. dorsalis. Obviously, such a number of trees are not enough to realize the reproductive potential of M. dorsalis, a significant part of them dies without laying eggs.

There is a small likelihood that such specialized phytophages will develop new feed plants in the near future. The seeds of other legumes were proposed as feed for the larvae, on which the females began to lay their eggs 1-5 days later, as compared to honey locust, their lifespan was 2-5 days longer than females in containers with honey locust seeds. Larvae populated the seeds of other legumes reluctantly (table 1).

East Asian Seed Beetle did not colonize the seeds of Cicer arietinum and Lens culinaris while could colonize 10 and $40 \%$ of Phaseolus vulgaris and Vigna sesquipedalis respectively (galleries with dead larvae of the first instar were found in seeds).

Thus, the seeds of tested legumes were unsuitable for feeding larvae and larvae were not able to complete their development as well as most of the eggs laid in containers.

Seasonal development. Eggs of $M$. dorsalis develop 9 days at $24^{\circ} \mathrm{C}$ and 6 days at $27^{\circ} \mathrm{C}$. Hatching larvae actively crawl in search of food and a few hours after hatching begin to penetrate into the seeds, the place of the entrance is clearly visible by the cork from sawdust.

As a rule, one seed of honey locust is inhabited by one larva. In the laboratory conditions, $2-3 \%$ of the seeds were inhabited by larvae that are able to complete development, but the size of such beetles was 1.3-1.5 times less. At a temperature of $27^{\circ} \mathrm{C}$, the development of a generation from egg to imago lasts 37 days, at a temperature of $25^{\circ} \mathrm{C}-41$ days. Laboratory emerging of beetles continued for 13-16 days (August and July, respectively) (figs 3, 4). Thus, at least the first two generations of $M$. dorsalis under environmental conditions develop on beans of the past few years, females of the third generation can lay eggs on mature beans of the current year.

Table 1. Colonization of legume seeds with larvae of East Asian Seed Beetle

\begin{tabular}{l|c|c|c}
\hline \multirow{2}{*}{ Feed plant } & \multirow{2}{*}{$\begin{array}{c}\text { Total seeds } \\
\text { amount }\end{array}$} & amount & proportion, \% \\
\cline { 3 - 4 } & 20 & $16-20$ & $83-100$ \\
\hline Gleditsia triacanthos L. & 20 & 0 & 0 \\
Cicer arietinum L. & 20 & 0 & 0 \\
Lens culinaris Medik. & 20 & 8 & 40 \\
Vigna sesquipedalis Fruw & 10 & 1 & 10 \\
Phaseolus vulgaris L. & & & \\
\hline
\end{tabular}




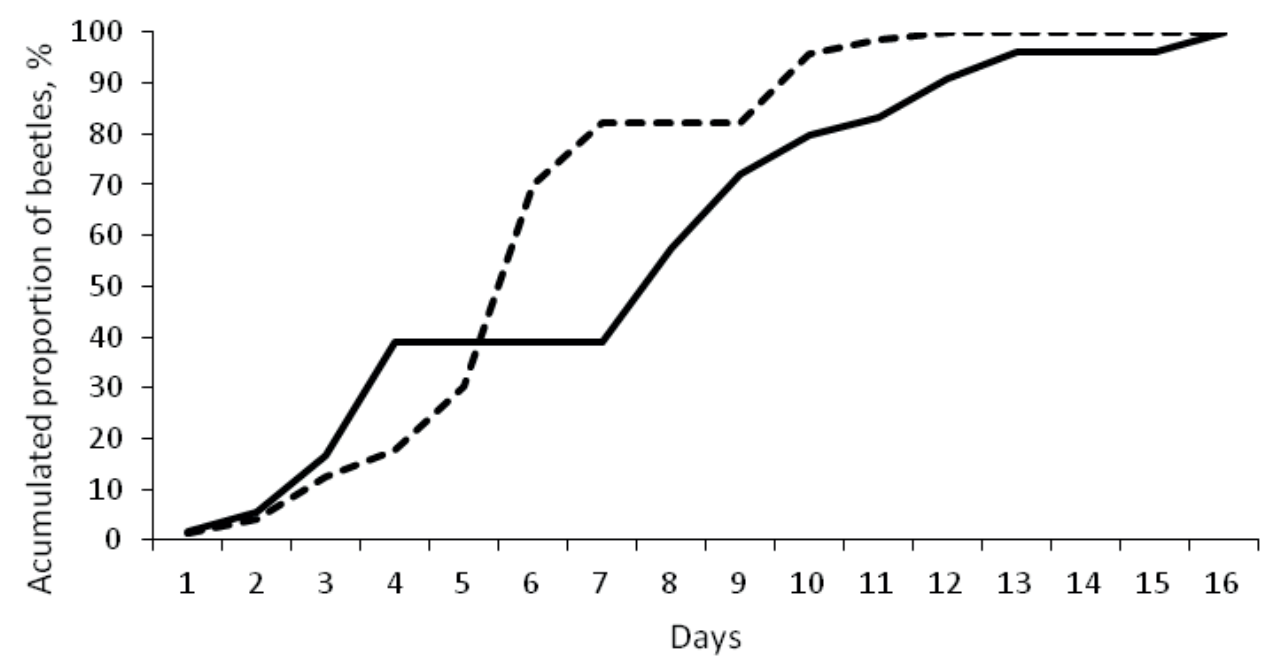

- July -- - August

Fig. 3. Accumulated emerging of East Asian seed beetle in the laboratory. July and August 2019.

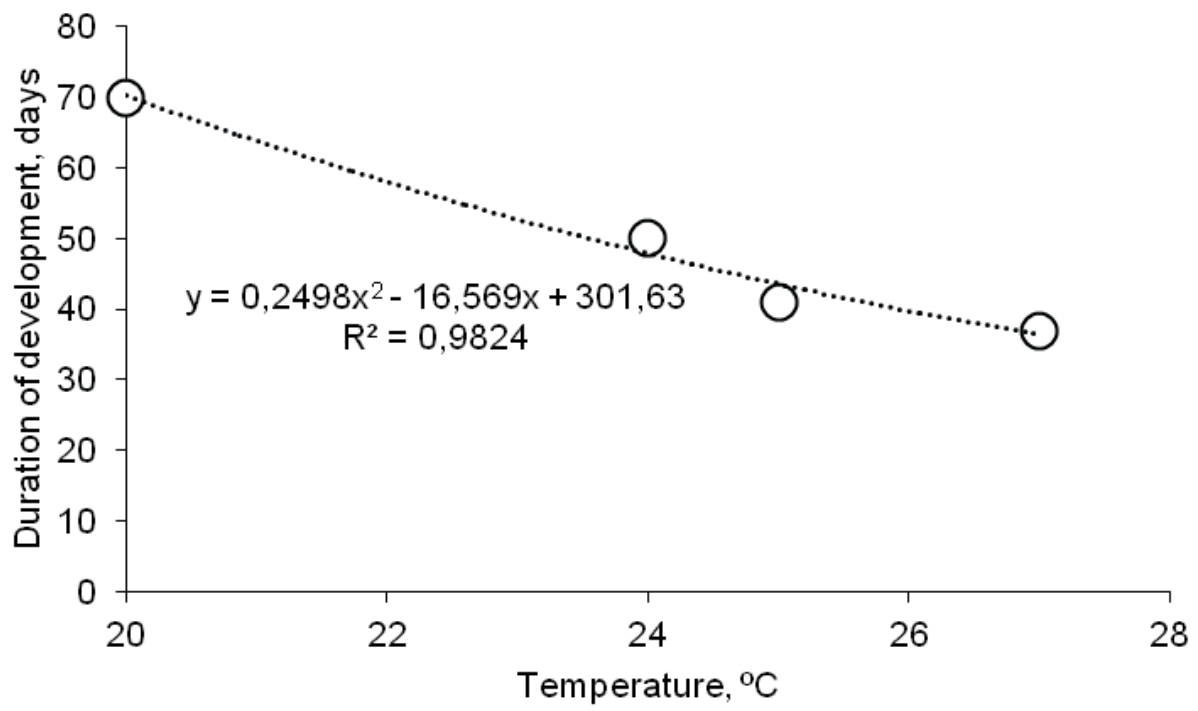

Fig. 4. Dependence of $M$. dorsalis development time on air temperature.

The ratio of males and females of East Asian seed beetle in the first laboratory generation was $1.4: 1$, in the second laboratory generation $1: 1$.

Under laboratory conditions, insects developed together, both oviposition and hatching of larvae occurred for a short time, due to the constancy of the temperature and humidity conditions (table 2). With a decrease in average air temperature by two degrees, the developmental time of generation increased by four days. Based on the obtained data, M. dorsalis in the Kharkiv Region can produce up to three generations.

The mass emergence of the first generation beetles in the laboratory was observed on July 5. At this time, seeds in beans were just beginning to form. In our conditions, the seeds of honey locust suitable for the development of larvae formed by the second decade of August. Thus, as in the natural range, in the Kharkiv Region, an East Asian Seed Beetles during 
Table 2. Phenology of East Asian Seed Beetle in laboratory

\begin{tabular}{l|c|c}
\hline \multirow{2}{*}{\multicolumn{1}{c}{ Parameters of development }} & \multicolumn{2}{c}{ Dates } \\
\cline { 2 - 3 } & $\begin{array}{c}\text { First generation } \\
\left(\mathrm{T}=27^{\circ} \mathrm{C}\right)\end{array}$ & $\begin{array}{c}\text { Second generation } \\
\left(\mathrm{T}=25^{\circ} \mathrm{C}\right)\end{array}$ \\
\hline Start of oviposition & May 25 & July 11 \\
Mass oviposition & May 26 & July 13 \\
Start of larvae hatching & June 2 & July 21 \\
Mass larvae hatching & June 3 & July 22 \\
Start of beetles emerging & June 30 & August 20 \\
Mass beetles emerging & July 5 & August 26 \\
\hline
\end{tabular}

the most part of the growing season use the seeds of the previous years as a feed substrate and only from the second half of August they can develop on the seeds of the current year.

Lifespan of adults of $M$. dorsalis is 15-30 days. In laboratory conditions at a temperature of $24-27^{\circ} \mathrm{C}$, the female lays $110 \pm 40$ eggs. Intensive egg lying lasts $4-5$ days, after which females lay single eggs.

\section{Discussion}

While comparing the life cycle of seed beetles, it is important to take into account the temperature regime in the regions (fig. 5). The temperature in Kharkiv from the end of April to June exceeds the same one in Nagano Prefecture by $1-3{ }^{\circ} \mathrm{C}$, which leads to an earlier emergence of East Asian Seed Beetles (first decade of May), and thus the timing of their appearance corresponds to the southern part of the range in Japan (Sanamiharo). Starting in July, the summer period, as well as the autumn and winter periods in Kharkiv were colder than in Nagano. From July to December, the temperature in Kharkiv was lower by $1-3{ }^{\circ} \mathrm{C}$ (see fig. 5 ).

In the Kharkiv Region, as well as in Nagano, adults, and larvae of the last age hibernate, however, in Kharkiv a small part of specimens $(11 \%)$ hibernates at the pupa stage.
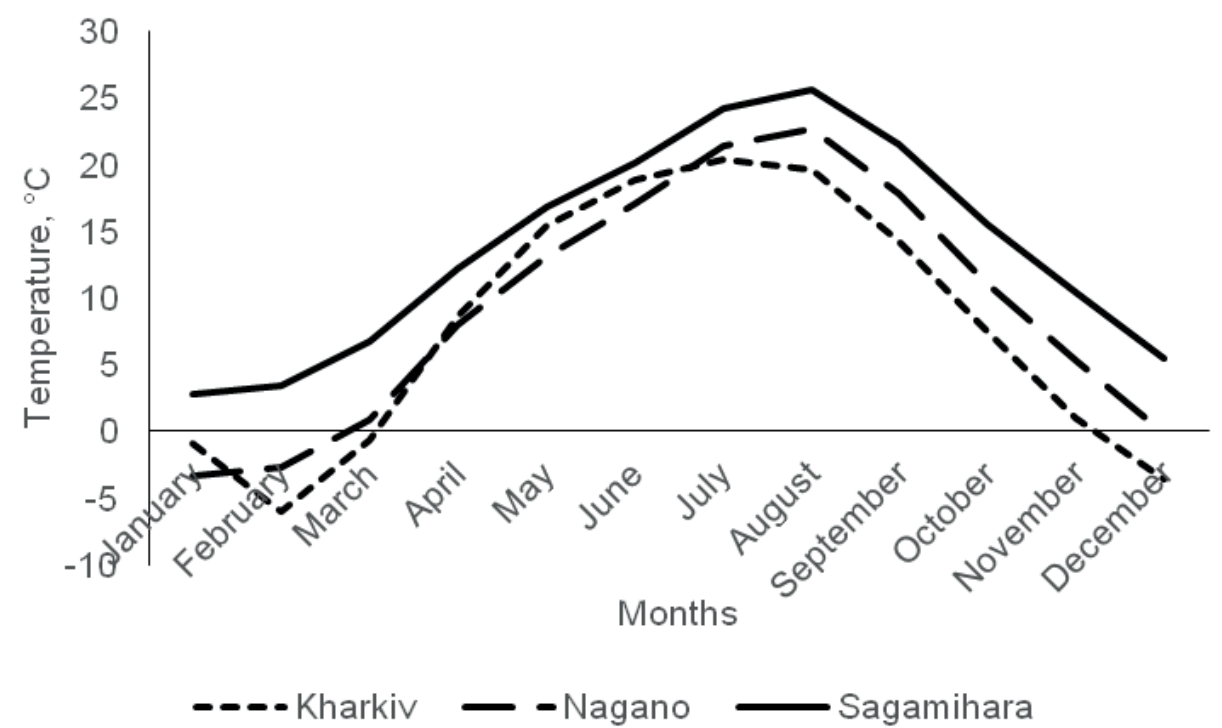

Fig. 5. Air temperature in different regions of $M$. dorsalis range. 
In Nagano, two, or possibly three, generations of $M$. dorsalis per year can develop (Kurota, 2002), so three generations also may develop in the Kharkiv Region due to both similar the temperature regime and the phenology of the host plant. Honey locust seeds in the Kharkiv Region ripen about two weeks earlier than in Nagano. Therefore, and from eggs laid on beans of a new crop, larvae of the last age, pupa or imago may develop.

Japanese researchers (Kurota, Shimada, 2002) have discovered an interesting feature of $M$. dorsalis. Due to the lack of seeds from last year's crop, they do not breed from July until the beginning (Sanamiharo) or the end (Nagano) of August. This shortage is partly due to the destruction of beans lying on the soil at high humidity, because the annual precipitation in Nagano is $1288 \mathrm{~mm}$, in Sanamiharo $1553 \mathrm{~mm}$. In the Kharkiv Region, due to a drier climate (annual rainfall is $527 \mathrm{~mm}$ ), last year's beans are still suitable for beetles for at least two years, which makes it possible for an $M$. dorsalis to use them for breeding.

Maturation feeding. In a publication on the biology of a closely related species Megabruchidius tonkineus, it is indicated that a honey solution was used as a maturation feeding for adults (György, 2007). As indicated above, only males of M. dorsalis in the natural range feed on nectar and pollen (Takakura, 2006). Male nutritional status does not affect female fertility (Takakura, 2004, 2009). Our research showed that the nutrition of beetles with carbohydrate solutions in laboratory conditions is caused precisely by the need to obtain moisture. However, like bean beetle (Acanthoscelides obtectus) (Pavlushin, Lazarev, 2005), these insects can successfully reproduce without maturation feeding of adults, as evidenced by their successful propagation in the absence of water and sources of carbohydrates. Apparently, this property of adults was the reason that B. A. Korotyaev (2011) was not able to detect beetles of a close species Megabruchidius tonkineus when using hand net on the flowering vegetation near the honey locust trees. We also did not find bugs on flowering vegetation. Perhaps the males of the overwintered beetles do not need maturation feeding with nectar and pollen.

Emerging. The dynamics of emerging of the beetles of the first and second laboratory generations of $M$. dorsalis had its own features. In July, the beetles emerged more evenly the main part of them emerged within seven days (fig. 6). In August, hatching occurred more synchronously, the majority of insects emerged within four days. Such features are probably associated with the photoperiodic reaction of $M$. dorsalis, which are characterized by multivoltinism.

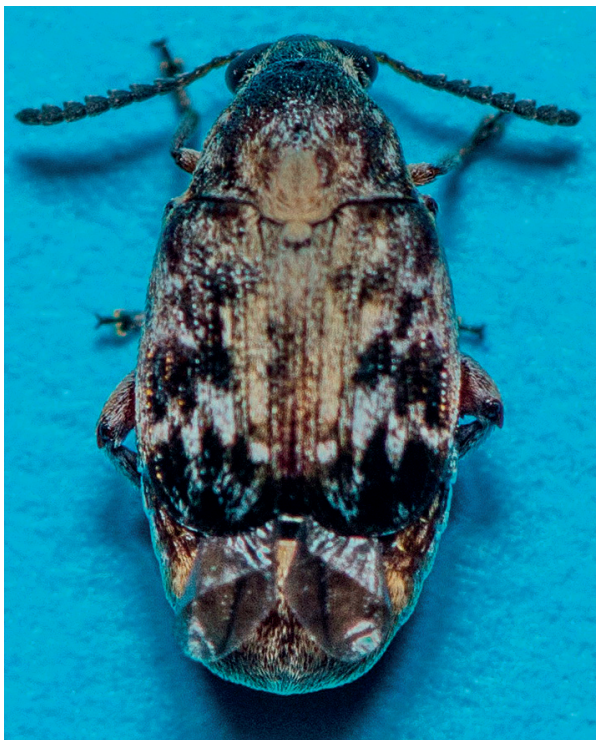

Fig. 6. Adult Megabruchidius dorsalis. (Photo by M. A. Filatov).
It is known that the multivoltine seasonal cycle is characterized by the fact that the overwintered generation gives rise to successive summer generations, the series of which ends with diapause and hibernation. The environmental regulation of multivoltinism is based on photoperiodic reactions of a long-day type (Saulich, Musolin, 2014).

Mass emerging of beetles of the first laboratory generation occurred during the photoperiod of $16.13: 7.47 \mathrm{~h}$ light/dark, of the second generation $13.52: 10.8 \mathrm{~h}$ light/ dark. The second generation emerged at the end of August, at this time the current year's beans were already ripe, on which the females of this generation lay their eggs. Perhaps shortening the day length is a signal for the more simultaneous development of $M$. dorsalis and synchronization of their phenology and phenology of the feed plant. 
So, according to the publications (Kurota, Shimada, 2001) and our own data, one generation of $M$. dorsalis develops 70 days at a temperature of $20^{\circ} \mathrm{C}$, 50 days at $24^{\circ} \mathrm{C}, 41$ days at $25^{\circ} \mathrm{C}$, 37 days at $27^{\circ} \mathrm{C}$ (see fig. 4 ).

The mass emergence of the first generation beetles in the laboratory was observed on July 5 . At this time, seeds began to form in beans in the trees (fig. 7).

In conditions of the Kharkiv Region, honey locust seeds suitable for larvae development formed by the second decade of August. Thus, as in the natural range, in the North-East of Ukraine (Kharkiv Region), M. dorsalis throughout most of the growing season uses the seeds of the harvest of past years as a feed substrate and only from the second half of August develops in the seeds of the current year.

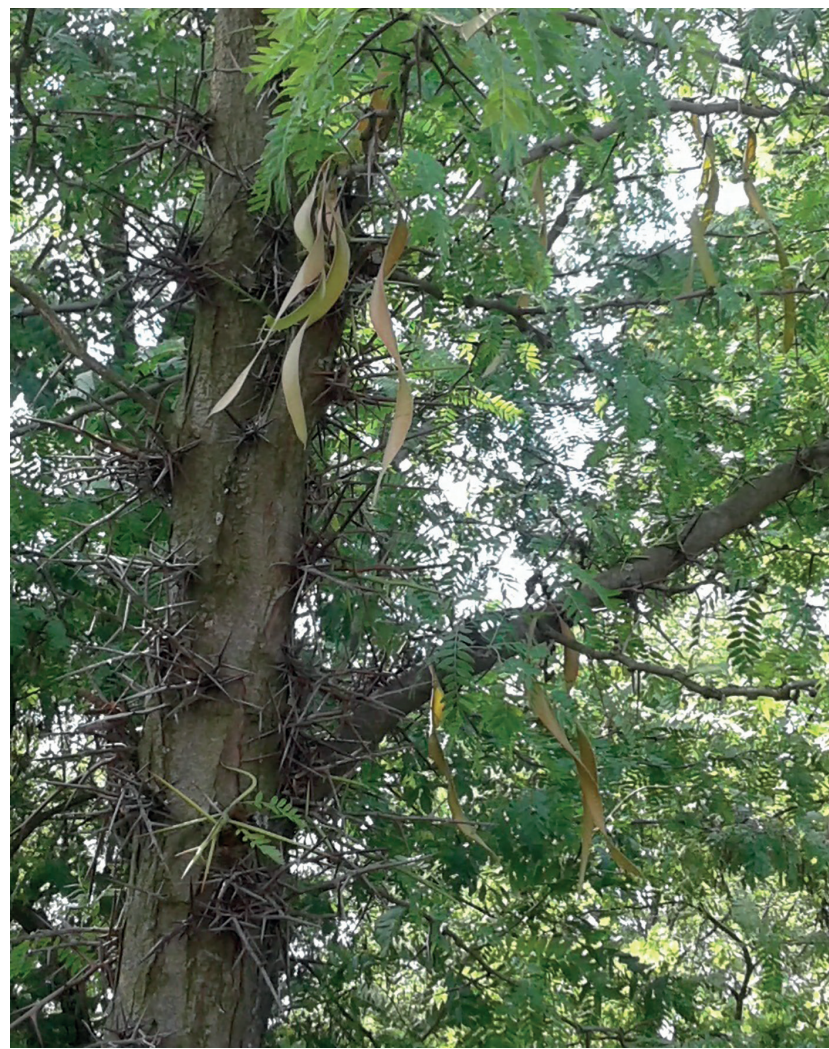

\section{Conclusions}

Fig. 7. Gleditsia triacanthos with ripen beans (Photo by Yu. V. Vasilieva).

East Asian Seed Beetle, Megabruchidius dorsalis, hibernates in the Kharkiv Region, in the northern part of the range in Japan (Nagano), in the stages of adults (28\%) and larvae of the last age (61\%). However, in Kharkiv, a small proportion of specimens (11\%) hibernates in the pupa stage. They hibernate in beans on the soil, in beans in trees, and in shelters.

The first adults of Megabruchidius dorsalis were found after hibernation in the first decade of May, which corresponds to the dates of their appearance in southern Japan (Sanamiharo). Beetles do not need maturation feeding, use water, but it's not necessary. The presence of a fodder substrate for $M$. dorsalis larvae - honey locust beans is a signal for mating and oviposition. In the presence of only seeds of this plant, mating and oviposition begin 8-11 days after emerging the beetles, and in the presence of beans, in two days.

The fertility of $M$. dorsalis females in the laboratory is $110 \pm 40$ eggs. Egg mortality in natural conditions is $50-93 \%$. Embryonic development lasts 9 days at a temperature of $24^{\circ} \mathrm{C}$ and 6 days at a temperature of $27^{\circ} \mathrm{C}$. At a temperature of $27^{\circ} \mathrm{C}$, the development of a generation lasts 37 days, at a temperature of $25^{\circ} \mathrm{C}-41$ days.

East Asian Seed Beetle did not colonize the seeds of Cicer arietinum and Lens culinaris. The larvae of the first age died in Phaseolus vulgaris and Vigna sesquipedalis seeds.

Both in Japan and in the Kharkiv Region, East Asian Seed Beetles oviposit into honey locust seeds from the last year's harvest and use the current year seeds only from the second half of August.

$M$. dorsalis in the Kharkiv Region can produce up to three generations due to warmer spring and earlier ripening of honey locust seeds, compared with the northern part of the range in Japan. It is connected with the temperature regime and the phenology of the host plant. Honey locust seeds in the Kharkiv Region ripen about two weeks earlier than in Nagano, and eggs laid on beans of a new crop have time to develop to last-instar larvae, pupae, or adults. 
The authors would like to express their gratitude to M. A. Filatov (V. V. Dokuchaev Kharkiv National Agrarian University) for your assistance in photographing insects, student Yu. S. Kharchenko (Kharkiv National Agrarian University) V. Dokuchaev) for assistance in research, Professor V. L. Meshkova (Ukrainian Research Institute of Forestry and Forest Melioration named after G. M. Vysotsky) for methodological assistance in preparing the paper.

\section{References}

About modification of the List of regulated harmful organisms. DOI: https://zakon.rada.gov.ua/laws/main/ z0879-19 Accessed 9.05.2020 [In Ukrainian].

Climate data of cities worldwide. Available at: https:// ru.climate-data.org

Fursov, V., Nazarenko, V. 2015. Invasive Species Megabruchidius dorsalis (Coleoptera, Chrysomelidae, Bruchinae) - a New Record in the Fauna of Ukraine. Vestnik Zoologii, 49 (3), 286. DOI: https://doi.org/10.1515/ vZoo-2015-0029.

György, Z. 2007. To the biology of the honey locust seed beetle, Megabruchidius tonkineus (Pic, 1904) (Coleoptera: Chrysomelidae: Bruchinae). Folia Entomologica Hungarica, 68, 89-96.

URL: http://publication.nhmus.hu/pdf/folentom/FoliaEntHung_2007_Vol_68_89.pdf.

Korotyaev, B. A. 2011. On Invasion of an East Asian Seed Beetle, Megabruchidius tonkineus (Pic) (Coleoptera, Bruchidae), Developing in Gleditsia Seeds, in the Northwest Caucasus. Entomological Review, 91 (9), 1167-1169. DOI: DOI: https://doi.org/10.1134/S0013873811090089

Kurota, H., Shimada, M. 2001. Photoperiod and temperature-dependent induction of larval diapause in a multivoltine bruchid, Bruchidius dorsalis. Entomologia Experimentalis et Applicata. 99 (3), 361-369. DOI: https://doi.org/10.1046/j.1570-7458.2001.00836.x

Kurota, H., Shimada, M. 2002. Geographical Variation in the Seasonal Population Dynamics of Bruchidius dorsalis (Coleoptera: Bruchidae): Constraints of Temperature and Host Plant Phenology. Environmental Entomology, 31 (3), 469-475. DOI: https://doi.org/10.1603/0046-225X-31.3.469

Lezhenina, I., Vasylieva, Yu. 2018. Megabruchidius dorsalis (Fåhreus, 1839) is a new adventive species in the Kharkiv region (Ukraine). The Kharkov Entomological Society Gazette, 25 (1), 15-18. DOI: https://doi. org/10.36016/KhESG-2018-26-2-3

Martynov, V. V., Nikulina, T. V. 2014. The first finding of invasive species Megabruchidius dorsalis (Fåhraeus, 1839) (Coleoptera: Chrisomelidae: Bruchinae) in the fauna of Ukraine. Vestnik Zoologii, 48 (3), 286. DOI: https://doi.org/10.2478/vzoo-2014-0034

Orlova-Bienkowskaja, M. J., ed. 2019. Inventory on alien beetles of European Russia. Mukhametov G. V., Livny, $1-550$.

Pavlushin, V. A., Lazarev, A. M. 2005. Bean bruchid. Plant Protection and Quarantine, 12, 34-45 [In Russian].

Saulich, A. H., Musolin, D. L. 2014. Seasonal cycles of the temperate zone pentatomids (Heteroptera, Pentatomidae): diversity and regulation. Entomological review, 93 (2), 263-302 [In Russian].

Shoven, R. 1953. Insect Physiology. Publishing House of Foreign Literature, Moscow, 304-309 [In Russian].

Takakura, K. 2004 a. Estimation of relative reproductive expenditure in the courtship-role-reversed bean weevil, Bruchidius dorsalis (Fahraeus). https://www.researchgate.net/journal/0289-0771. Journal of Ethology, $22(1), 37-42$.

Takakura, K. 2004 b. Variation in Egg Size Within and Among Generations of the Bean Weevil, Bruchidius dorsalis (Coleoptera, Bruchidae): Effects of Host Plant Quality and Paternal Nutritional Investment. Annals of the Entomological Society of America, 97 (2), 346-352. DOI: https://doi.org/10.1093/aesa/97.2.3461

Takakura, K. 2006. The nutritional contribution of males affects the feeding behavior and spatial distribution of females in a bruchid beetle, Bruchidius dorsalis. https://www.researchgate.net/journal/0289-0771. Journal of Ethology, 24 (1), 33-36. DOI: https://doi.org/10.1007/s10164-005-0157-3

Tuda, M., Morimoto, K. 2004. A New Species Megabruchidius sophorae (Coleoptera, Bruchidae), Feeding on Seeds of Styphnolobium (Fabaceae) New to Bruchidae. Zoological Science, 21 (1), 105-110. DOI: https:// doi.org/10.2108/0289-0003(2004)21[105:ANSMSC]2.0.CO;2

Received 11 June 2020

Accepted 25 August 2020 